\title{
Retraction Note: Resistance to acid attack, abrasion and leaching behavior of alkali-activated mine waste binders
}

\author{
Pacheco-Torgal Fernando $\cdot$ Jalali Said
}

Accepted: 10 June 2021 / Published online: 9 July 2021

(C) RILEM 2021

1 Retraction: Materials and Structures (2011) 44:487-498 https://doi.org/10.1617/s11527-010-9643-3

The Editor-in-Chief has retracted this article because it significantly overlaps with previously published article by Pacheco-Torgal et al. $[1,2]$ and an article that was simultaneously under consideration at another journal [3].

Fernando Pacheco-Torgal does not agree to this retraction. Said Jalali has not responded to correspondence regarding this retraction.

\section{References}

1. Pacheco-Torgal F, Castro-Gomes J, Jalali S (2007) Investigations about the effect of aggregates on strength and microstructure of geopolymeric mine waste mud binders. Cem Concr Res 37(6):933-941 https://doi.org/10.1016/j. cemconres.2007.02.006

2. Pacheco-Torgal F, Castro-Gomes J, Jalali S (2008) Properties of tungsten mine waste geopolymeric binder. Constr Build Mater 22(6):1201-1211 https://doi.org/10.1016/j. conbuildmat.2007.01.022

3. Fernando P-T, João C-G, Said J (2010) Durability and environmental performance of alkali-activated tungsten mine waste mud mortars. J Mater Civ Eng 22(9):897-904 https:// doi.org/10.1061/(ASCE)MT.1943-5533.0000092

Publisher's Note Springer Nature remains neutral with regard to jurisdictional claims in published maps and institutional affiliations.
The original article can be found online at https:// doi.org/10.1617/s11527-010-9643-3.

P.-T. Fernando $(\bowtie)$

CTAC Research Unit, University of Minho,

4800 Guimaraes, Portugal

e-mail: torgal@civil.uminho.pt

J. Said

Department of Civil Engineering, University of Minho,

4800 Guimaraes, Portugal

e-mail: said@civil.uminho.pt 